\title{
Blood calcium dynamics after prophylactic treatment of subclinical hypocalcemia with oral or intravenous calcium
}

\author{
C. D. Blanc, ${ }^{*}$ M. Van der List, $†$ S. S. Aly, $¥ \S$ H. A. Rossow, $¥ \S$ and N. Silva-del-Río $¥ \S^{1}$ \\ ${ }^{*}$ Pacific Rim Dairy, 13406 Road 24 Corcoran, CA 93212 \\ †Boehringer Ingelheim, 5501 Corporate Dr., St. Joseph, MO 64507 \\ $\ddagger$ Veterinary Medicine Teaching and Research Center, 18830 Road 112, Tulare, CA 93274 \\ $\S$ Department of Population Health and Reproduction, School of Veterinary Medicine, University of California-Davis, One Shields Avenue, \\ Davis 95616
}

\begin{abstract}
Total serum Ca dynamics and urine $\mathrm{pH}$ levels were evaluated after prophylactic treatment of subclinical hypocalcemia after parturition in 33 multiparous Jersey $\times$ Holstein crossbreed cows. Cows were blocked according to their calcemic status at the time of treatment [normocalcemic $(8.0-9.9 \mathrm{mg} / \mathrm{dL} ; \mathrm{n}=15)$ or hypocalcemic $(5.0-7.9 \mathrm{mg} / \mathrm{dL} ; \mathrm{n}=18)]$ and randomly assigned to 1 of 3 treatments: control [no Ca supplementation $(\mathrm{n}=11)]$; intravenous Ca [Ca-IV $(\mathrm{n}=11), 500 \mathrm{~mL}$ of $23 \%$ calcium gluconate (10.7 $\mathrm{g}$ of $\mathrm{Ca}$ and $17.5 \mathrm{~g}$ of boric acid as a solubilizing agent; Durvet, Blue Springs, $\mathrm{MO})]$; or oral $\mathrm{Ca}$ [Ca-Oral $(\mathrm{n}=11), 1$ oral bolus (Bovikalc bolus, Boehringer Ingelheim, St. Joseph, MO) containing $\mathrm{CaCl}_{2}$ and $\mathrm{CaSO}_{4}(43 \mathrm{~g}$ of $\mathrm{Ca}) 2$ times 12 $\mathrm{h}$ apart]. Total serum Ca levels were evaluated at 0,1 , $2,4,8,12,16,20,24,36$, and $48 \mathrm{~h}$, and urine $\mathrm{pH}$ was evaluated at $0,1,12,24,36$, and $48 \mathrm{~h}$ after treatment initiation. Total serum Ca levels were higher for Ca-IV than for control and Ca-Oral cows at 1, 2, and $4 \mathrm{~h}$ after treatment initiation, but lower than Ca-Oral cows at 20, 24, and $36 \mathrm{~h}$ and lower than control cows at 36 and $48 \mathrm{~h}$. At $1 \mathrm{~h}$ after treatment initiation, when serum Ca levels for Ca-IV cows peaked $(11.4 \mathrm{mg} / \mathrm{dL})$, a greater proportion of $\mathrm{Ca}-\mathrm{IV}(\mathrm{n}=8)$ cows had total serum $\mathrm{Ca}$ levels $>10 \mathrm{mg} / \mathrm{dL}$ than control $(\mathrm{n}=0)$ and Ca-Oral (n $=1$ ) cows. At $24 \mathrm{~h}$ after treatment initiation, when CaIV cows reached the total serum Ca nadir $(6.4 \mathrm{mg} / \mathrm{dL})$, a greater proportion of Ca-IV $(\mathrm{n}=10)$ cows had serum Ca levels $<8 \mathrm{mg} / \mathrm{dL}$ than control $(\mathrm{n}=5)$ and Ca-Oral $(\mathrm{n}=2)$ cows. Treatment, time, and treatment $\times$ time interaction were significant for urine $\mathrm{pH}$. Mean urine $\mathrm{pH}$ was lower for Ca-Oral cows (6.69) than for control (7.52) and Ca-IV (7.19) cows. Urine $\mathrm{pH}$ levels at $1 \mathrm{~h}$ after treatment were lower for Ca-IV cows compared with both control and $\mathrm{Ca}$-Oral cows, a finding likely
\end{abstract}

Received January 9, 2014

Accepted July 18, 2014.

${ }^{1}$ Corresponding author: nsilvadelrio@ucdavis.edu associated with the iatrogenic administration of boric acid added as a solubilizing agent of the intravenous Ca solution used. At 12, 24, and $36 \mathrm{~h}$, urine $\mathrm{pH}$ levels were lower for Ca-Oral cows compared with both control and Ca-IV cows. This was expected because the oral Ca supplementation used (Bovikalc) is designed as an acidifying agent. Wide fluctuations in blood $\mathrm{Ca}$ were observed after prophylactic intravenous Ca supplementation. The implications for milk production and animal health, if any, of these transient changes in total serum Ca have yet to be evaluated.

Key words: hypocalcemia, hypercalcemia, calcium homeostasis

\section{INTRODUCTION}

Hypocalcemia is a common metabolic disease of dairy cows after parturition. In the United States, the incidence of clinical hypocalcemia has been reported to be $5 \%$, whereas subclinical hypocalcemia can be as high as 54\% in multiparous cows (Reinhardt et al., 2011). Hypocalcemia has important consequences because $\mathrm{Ca}$ is essential for skeletal and smooth muscle contraction as well as for immune function (Kimura et al., 2006). Clinical hypocalcemia has been associated with dystocia, uterine prolapse, retained placenta, endometritis, decreased fertility, mastitis, and decreased rumen and abomasum motility (Curtis et al., 1983; Borsberry and Dobson, 1989; Goff et al., 2004). Similarly, cows with subclinical hypocalcemia are at a greater risk for metritis (Martinez et al., 2012), displaced abomasum (Chapinal et al., 2011), and culling (Roberts et al., 2012), and show an impaired hepatic lipid metabolism (Chamberlin et al., 2013).

To prevent clinical and subclinical hypocalcemia, some dairy herds may benefit from implementing prophylactic strategies. One approach is to feed anionic salts prepartum. This strategy has been reported to significantly reduce the incidence of clinical hypocalcemia (Charbonneau et al., 2006). However, feeding anionic salts has decreased the incidence of subclinical hypo- 
calcemia in some studies (Oetzel et al., 1988; Moore et al., 2000), but failed to do so in others (Ramos-Nieves et al., 2009). A different strategy is the prophylactic treatment of hypocalcemia with oral or intravenous Ca supplementation immediately after calving. The benefits of supplementing Ca to cows fed a low-DCAD diet require further investigation. Melendez et al. (2002) failed to find any effect on plasma $\mathrm{Ca}, \mathrm{P}, \mathrm{Mg}, \mathrm{NEFA}$, BHBA, or glucose when cows fed anionic salts prepartum were supplemented immediately after calving with various sources of $\mathrm{Ca}$ either orally ( $\mathrm{Ca}$ chloride, $\mathrm{Ca}$ propionate, and $\mathrm{Ca}$ propylene glycol) or intravenously (Ca gluconate). However, sampling frequency $(2,3,6$, 9 , and $12 \mathrm{~d}$ after calving) in that study was inadequate to evaluate the short-term effects of Ca supplementation on plasma constituents. However, in a different study, lame cows and high-producing multiparous cows benefited from oral Ca supplementation even when lowDCAD diets were fed (Oetzel and Miller, 2012).

Calcium hemodynamics after prophylactic Ca supplementation may vary with route of administration. Intravenous Ca treatment of clinical hypocalcemia results in a rapid increase of serum $\mathrm{Ca}$, reaching concentrations that could be toxic. Results from an uncontrolled study indicated that hypercalcemia is followed by a steep decline that leads to a transient hypocalcemic stage (Braun et al., 2009).

The effect of administering $\mathrm{Ca}$ as a prophylactic treatment after parturition on $\mathrm{Ca}$ hemodynamics is unknown. Thus, the objective of this study was to evaluate total serum Ca dynamics in dairy cows after prophylactic treatment of hypocalcemia with oral and intravenous sources of Ca.

\section{MATERIALS AND METHODS}

All procedures were approved by The Institutional Animal Care and Use Committee (IACUC) at the University of California Davis, School of Veterinary Medicine.

\section{Cows and Herd Management}

The study was conducted on a commercial freestall dairy farm in California with 8,000 Jersey and Jerseycross lactating cows with an average milk yield per day of $27 \mathrm{~kg}$. Thirty-three multiparous cows in their third or greater lactations were enrolled. The study was conducted in February 2013 over an 8-d period.

During the last 3 wk of gestation, cows were housed in a dry-lot facility until they showed primary signs of calving. Close-up cow diets were offered ad libitum, once a day, a TMR with anionic salts included in the mineral mix (Table 1). Then, cows were moved to a covered loafing maternity pen. Immediately after parturition, calves were separated from dams. Within $4 \mathrm{~h}$ after parturition, cows were moved to an open dry-lot pen for 2 to $3 \mathrm{~d}$ until milk was clear of dry-cow treatment antibiotic residues. Postpartum cows were milked twice a day and fed a TMR once a day (Table 1). At the study onset, feedbunk TMR samples of close-up and fresh cow diets were collected for wet chemistry analysis (Table 1; Dairyland Laboratories, St. Cloud, $\mathrm{MN})$.

\section{Experimental Design}

Treatments were arranged in a randomized block design. Immediately after calving ( 1 to $3 \mathrm{~h}$ postcalving), total serum Ca levels were determined by using a portable blood analyzer (Vetscan 200-1000R, Abaxis Veterinary Diagnostics, Union City, CA) and used to block cows as normocalcemic $(8.0-9.9 \mathrm{mg} / \mathrm{dL} ; \mathrm{n}=15)$ or hypocalcemic $(5.0-7.9 \mathrm{mg} / \mathrm{dL} ; \mathrm{n}=18)$. Within each

Table 1. Ingredients and nutrient composition of close-up and fresh cow rations

\begin{tabular}{|c|c|c|}
\hline Item & Close-up & Fresh \\
\hline \multicolumn{3}{|l|}{ Ingredient ( $\%$ of DM) } \\
\hline Alfalfa hay & 25.2 & 19.6 \\
\hline Almond hulls & - & 7.6 \\
\hline Canola meal & 9.2 & 8.8 \\
\hline Close-up mineral $^{1}$ & 5.5 & - \\
\hline Corn gluten feed & - & 9.6 \\
\hline Corn silage & 15.1 & 10.0 \\
\hline Lactating cow mineral $^{1}$ & - & 2.4 \\
\hline Prequel $\Omega 3$ bypass $^{2}$ & 1.0 & - \\
\hline Rolled corn & 17.4 & 18.0 \\
\hline Water & 0.4 & - \\
\hline Wet distillers grain & 7.4 & - \\
\hline Wheat silage & 14.7 & 12.1 \\
\hline Wheat straw & 4.1 & - \\
\hline Whey & - & 3.8 \\
\hline \multirow{2}{*}{\multicolumn{3}{|c|}{ Nutrient composition ${ }^{3}$ (DM basis) }} \\
\hline & & \\
\hline $\mathrm{CP}(\%)$ & 15.3 & 18.0 \\
\hline $\operatorname{ADF}(\%)$ & 19.9 & 19.3 \\
\hline $\operatorname{NDF}(\%)$ & 30.0 & 30.2 \\
\hline Lignin (\%) & 3.5 & 4.0 \\
\hline Starch $(\%)$ & 23.2 & 21.3 \\
\hline Ether extract (\%) & 3.4 & 5.6 \\
\hline Ash (\%) & 10.1 & 9.2 \\
\hline $\mathrm{Ca}(\%)$ & 1.97 & 1.13 \\
\hline $\mathrm{P}(\%)$ & 0.45 & 0.5 \\
\hline $\operatorname{Mg}(\%)$ & 0.52 & 0.37 \\
\hline $\mathrm{K}(\%)$ & 1.57 & 1.46 \\
\hline $\mathrm{S}(\%)$ & 0.52 & 0.32 \\
\hline $\mathrm{Na}(\%)$ & 0.46 & 0.52 \\
\hline $\mathrm{Cl}(\%)$ & 1.6 & 0.75 \\
\hline $\operatorname{DCAD}^{4}(\mathrm{mEq} / 100 \mathrm{~g})$ & -17.40 & 18.84 \\
\hline
\end{tabular}

${ }^{1}$ Nutrius LLC (Kingsburg, CA).

${ }^{2}$ Virtus Nutrition LLC (Corcoran, CA).

${ }^{3}$ Wet chemistry analysis (Dairyland Laboratories, St Cloud, MN). ${ }^{4} \mathrm{DCAD}$ calculations were performed according to the following equation: DCAD $(\mathrm{mEq} / 100 \mathrm{~g})=[(\mathrm{Na}+\mathrm{K})-(\mathrm{Cl}+\mathrm{S})]$. 
block, cows were randomly assigned to 1 of 3 treatments: control $(\mathrm{n}=11)$, intravenous Ca (Ca-IV, $\mathrm{n}$ $=11$ ), or oral $\mathrm{Ca}(\mathbf{C a}-O r a l, \mathrm{n}=11)$. Initial treatment was applied within 1 to $5 \mathrm{~h}$ after calving. Cows in control group received no Ca supplementation. Cows assigned to the Ca-IV treatment received $500 \mathrm{~mL}$ of $23 \% \mathrm{Ca}$ gluconate (10.7 $\mathrm{g}$ of $\mathrm{Ca}$ and $17.5 \mathrm{~g}$ of boric acid as a solubilizing agent; Durvet, Blue Springs, MO) in the right subcutaneous abdominal vein administered slowly over 15 min. During intravenous Ca administration, cows were observed for irregular breathing and muscle spasm. Cows assigned to Ca-Oral received an oral bolus (Bovikalc bolus, Boehringer Ingelheim, St. Joseph, MO) containing $\mathrm{CaCl}_{2}$ and $\mathrm{CaSO}_{4}$ (43 g of Ca) 2 times $12 \mathrm{~h}$ apart.

Description of all cows included in the study is presented in Table 2. No twinning occurred and no calving assistance was required for cows enrolled in the study. Two Ca-IV cows were initially enrolled in the study but had to be replaced. One cow had severe mastitis $24 \mathrm{~h}$ after calving, and another cow was mistakenly given a $\mathrm{Ca}$ bolus $12 \mathrm{~h}$ after intravenous $\mathrm{Ca}$ treatment. Data from these cows were not included in the final data set.

\section{Sample Collection and Laboratory Analysis}

Blood samples $(7 \mathrm{~mL})$ were collected from the coccygeal vein using an evacuated tube without anticoagulant (Vacutainer, Becton Dickinson Co., Franklin Lakes, NJ) and allowed to clot for $20 \mathrm{~min}$. Samples were centrifuged at $1,400 \times g$ for 15 min (Premiere centrifuge model xc-2000, Max RCF 1790g; C and A Scientific, Manassas, VA). Blood was collected at 0, 1, $2,4,8,12,16,20,24,36$, and $48 \mathrm{~h}$ relative to treatment application. Serum was separated and stored frozen at $-20^{\circ} \mathrm{C}$ until analysis. Upon completion of the trial, serum samples were sent overnight on dry ice for analysis (Marshfield Lab, Marshfield, WI) of total Ca using the enzymatic rate/automated chemistry analyzer method (arsenazo III; Michaylova and Ilkova, 1971) with a
Beckman Coulter analyzer (Beckman Coulter Inc., Brea, CA).

Urine was sampled by midstream catch at $0,1,12$, 24,36 , and $48 \mathrm{~h}$ after treatment application. Urine $\mathrm{pH}$ was measured on-farm with Oakton pH Testr 20 (Oakton Instruments, Vernon Hills, IL), calibrated once a day with $\mathrm{pH}$ 4.0, 7.0, and 10.0 standard solutions.

\section{Statistical Analyses}

The general linear models procedure of SAS (PROC GLM; SAS Institute Inc., Cary, NC) was used to evaluate whether pretreatment initiation lactation number, DIM at dry-off, days in close-up, 305-d mature-equivalent milk yield, total serum Ca levels, and urine $\mathrm{pH}$ were similar across treatment groups. Standard errors were obtained with the STDERR option of the LSMEANS statement. General linear mixed models with repeated measures (Littell et al., 1998) were used for the analyses of blood $\mathrm{Ca}$ and urine $\mathrm{pH}$ using the MIXED procedure of SAS (SAS Inst. Inc., Cary, NC) using Kenward-Rogers adjustment for calculation of denominator degrees of freedom. The covariance structure for repeated measurement was chosen based on the Akaike's information criterion (Littell et al., 1998). Total serum $\mathrm{Ca}$ and urine $\mathrm{pH}$ levels at $0 \mathrm{~h}$ relative to treatment application, respectively, were offered as a covariate for each of the models. The model included the effects of treatment, time, and treatment $\times$ time interaction. Block and cow were included as random terms and used as the error term to test for the effects of treatments. Variables were declared significant at $P<0.05$. Significant interactions of treatment $\times$ time were explored using the SLICE option of the LSMEANS statement of the MIXED procedure of SAS. Comparisons across treatments at each significant time point were conducted with the PDIFF option of the LSMEANS statement. Proportion of cows with serum $\mathrm{Ca}>10 \mathrm{mg} / \mathrm{dL}$ at $1 \mathrm{~h}$ after treatment initiation and $<8$ $\mathrm{mg} / \mathrm{dL}$ at $24 \mathrm{~h}$ was evaluated using the Fisher exact test with the FREQ procedure of SAS.

Table 2. Mean values of parameters describing cows before treatment initiation

\begin{tabular}{lrrrrr}
\hline & \multicolumn{3}{c}{ Treatment $^{1}$} & & \\
\cline { 2 - 4 } Item & Control & Ca-IV & Ca-Oral & SEM & $P$-value \\
\hline Lactation number & 3.40 & 3.60 & 3.60 & 0.99 & 0.89 \\
DIM at dry-off & 303.00 & 324.00 & 306.00 & 12.42 & 0.43 \\
Days in close-up & 18.67 & 21.51 & 22.68 & 1.59 & 0.29 \\
305-d mature-equivalent milk yield (kg) & $9,078.24$ & $9,497.20$ & $9,958.00$ & 555.89 & 0.54 \\
Total serum calcium (mg/dL) & 7.16 & 7.50 & 7.29 & 0.30 & 0.72 \\
Urine pH & 6.59 & 6.81 & 6.51 & 0.20 & 0.47 \\
\hline
\end{tabular}

${ }^{1}$ Control $=$ no treatment; Ca-IV $=500 \mathrm{~mL}$ of $23 \%$ calcium gluconate (Durvet, Blue Springs, MO) at postpartum; Ca-Oral = BoviKalc bolus (Boehringer Ingelheim, St. Joseph, MO) twice $12 \mathrm{~h}$ apart at postpartum. 


\section{RESULTS AND DISCUSSION}

\section{Total Serum Calcium}

To evaluate the effect of treatment on total serum Ca, data were adjusted by total serum $\mathrm{Ca}$ at $0 \mathrm{~h}$ relative to treatment. This covariate, although not significant $(P$ $=0.07)$, was kept in the model. Time and treatment $\times$ time interaction were significant $(P<0.001$; Figure 1$)$ for total serum Ca. The significant time $\times$ treatment interaction reflects the increase in serum Ca concentrations for Ca-IV cows, peaking at $1 \mathrm{~h}$ after treatment $(11.4 \mathrm{mg} / \mathrm{dL})$, followed by a decline that reached its nadir at $24 \mathrm{~h}$ after treatment $(6.4 \mathrm{mg} / \mathrm{dL})$. Calcium-IV cows had higher serum Ca than control and Ca-Oral cows at 1,2 , and $4 \mathrm{~h}$ after treatment. However, serum $\mathrm{Ca}$ was lower for Ca-IV cows than for Ca-Oral cows at 20, 24 and $36 \mathrm{~h}$ and lower than for control cows at 36 and $48 \mathrm{~h}$ (Figure 1).

At $1 \mathrm{~h}$ after treatment initiation, a greater $(P<$ 0.001) proportion of Ca-IV $(\mathrm{n}=8)$ cows had serum Ca levels $>10 \mathrm{mg} / \mathrm{dL}$ than control $(\mathrm{n}=0)$ and Ca-Oral $(\mathrm{n}=1)$ cows. Total serum Ca concentrations reached values up to $14.5 \mathrm{mg} / \mathrm{dL}$ in $\mathrm{Ca}-\mathrm{IV}$ cows. However, the present study might have failed to capture the highest total serum Ca concentration for Ca-IV cows, which likely occurred within minutes after treatment application (Braun et al., 2009). At $24 \mathrm{~h}$, when Ca-IV cows reached the total serum Ca nadir, a greater $(P=0.03)$ proportion of Ca-IV $(\mathrm{n}=10)$ cows had serum Ca levels $<8 \mathrm{mg} / \mathrm{dL}$ than control $(\mathrm{n}=5)$ and $\mathrm{Ca}-$ Oral $(\mathrm{n}=2)$ cows.

Similar findings were reported after treating clinical hypocalcemia $(\mathrm{n}=30)$ with various intravenous sources of Ca (Braun et al., 2009). Serum Ca rapidly increased, peaking 10 min after treatment; however, from 5 to $24 \mathrm{~h}$ after treatment, cows were in a transient hypocalcemic stage (Braun et al., 2009). The short-lived hypercalcemia observed after intravenous Ca supplementation alters the ability of the animal to maintain Ca homeostasis. According to Goff (1999), hypercalcemia causes a decrease in blood parathyroid hormone levels and an increase in thyrocalcitonin release, which decreases renal and bone $\mathrm{Ca}$ reabsorption, decreases calcitrol conversion to 1,25-dihydroxyvitamin $\mathrm{D}$, increases aciduria, and depletes blood of cations. Braun et al. (2009) observed a prompt suppression in parathyroid hormone

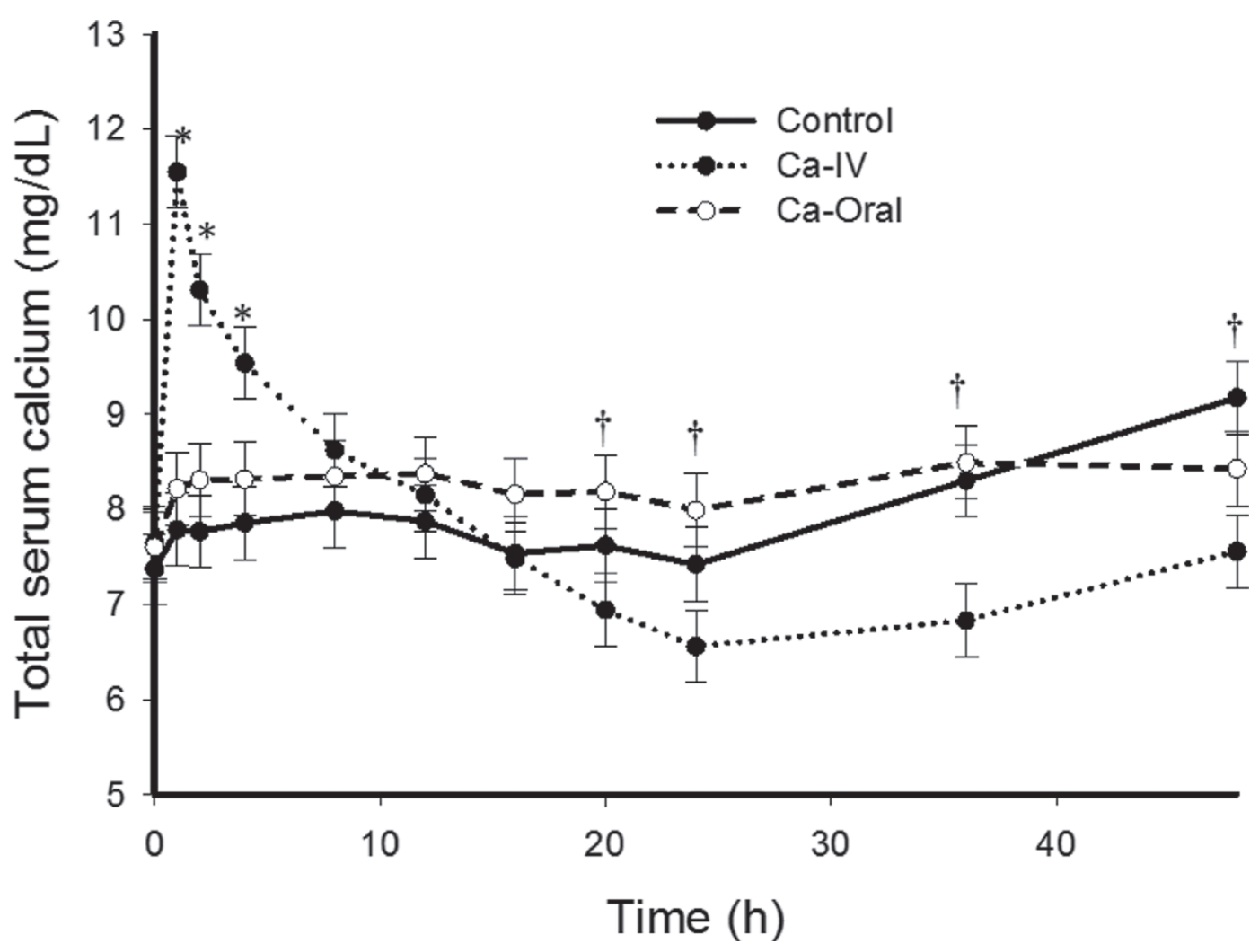

Figure 1. Total serum Ca levels (LSM \pm SEM) after postpartum prophylactic treatment of subclinical hypocalcemia in control (no Ca supplementation; $\mathrm{n}=11$ ), intravenous $\mathrm{Ca}$ [Ca-IV, $500 \mathrm{~mL}$ of $23 \%$ calcium gluconate (Durvet, Blue Springs, MO) at postpartum; $\mathrm{n}=11$ ], and oral Ca [Ca-Oral, 2 Bovikalc (Boehringer Ingelheim, St. Joseph, MO) boluses $12 \mathrm{~h}$ apart at postpartum; $\mathrm{n}=11)$ ]. We detected a significant $(P$ $<0.001)$ effect of time and treatment $\times$ time interaction. Significant treatment $\times$ time differences at each time point are indicated by $\dagger(P<$ $0.05)$ and $*(P<0.001)$. 
levels after treatment, followed by a slow increase and a subsequent decrease. The negative consequences of longer term hypocalcemia and hypercalcemia are well documented (Goff, 1999, 2004; Kimura et al., 2006, Chapinal et al., 2011). Nonetheless, the effects of this short, transient disruption in Ca homeostasis at parturition after intravenous administration of $\mathrm{Ca}$ are not known and have yet to be studied.

Total serum Ca levels for Ca-Oral were consistently numerically above those of control cows from 1 to 24 $\mathrm{h}$ after treatment but no statistical differences were detected $(P=0.22$; Figure 1$)$. The average difference in serum calcium between Ca-Oral and control cows was $0.35 \mathrm{mg} / \mathrm{dL}$. However, the current study had $80 \%$ power to declare significant differences above $0.60 \mathrm{mg} /$ dL. Similarly, Melendez et al. (2002), with 30 cows per treatment group, found no significant effect of oral Ca bolus supplementation on total Ca levels at 2, 3, 6, 9, and $12 \mathrm{~d}$ after parturition. In contrast, Sampson et al. (2009), with 10 cows per treatment group, found that postpartum oral Ca bolus supplementation increased serum Ca levels $1 \mathrm{~h}$ after the administration of the second Ca bolus. This increase in Ca was significant $(P<$ $0.05)$ for ionized Ca but was only a tendency $(P<0.09)$ for total Ca. In a recent large study including more than 800 cows, Oetzel and Miller (2012) evaluated the effects of oral Ca supplementation 8 to $35 \mathrm{~h}$ postcalving but detected no significant increase in ionized serum Ca concentration. Nevertheless, this study indicated that oral Ca bolus supplementation might benefit high-producing dams and lame cows, respectively, by increasing milk yield and reducing health events.

\section{Urine $\mathrm{pH}$}

To evaluate the effect of treatment on urine $\mathrm{pH}$, data were adjusted by urine $\mathrm{pH}$ at $0 \mathrm{~h}$ relative to treatment. This covariate was significant $(P=0.03)$ and therefore was kept in the model. Treatment, time, and treatment $\times$ time interaction were significant predictors of urine $\mathrm{pH}(P<0.001$; Figure 2). Mean urine $\mathrm{pH}$ was lower for cows treated with Ca-Oral (6.69) compared with both control (7.52) and Ca-IV (7.19) cows. We observed an effect of time and a treatment $\times$ time interaction $(P<$ 0.001). Mean urine $\mathrm{pH}$ levels at $1 \mathrm{~h}$ were lower for $\mathrm{Ca}-$ IV compared with both control and Ca-Oral. Although a direct association was not established, the aciduria observed for Ca-IV $1 \mathrm{~h}$ after treatment initiation might

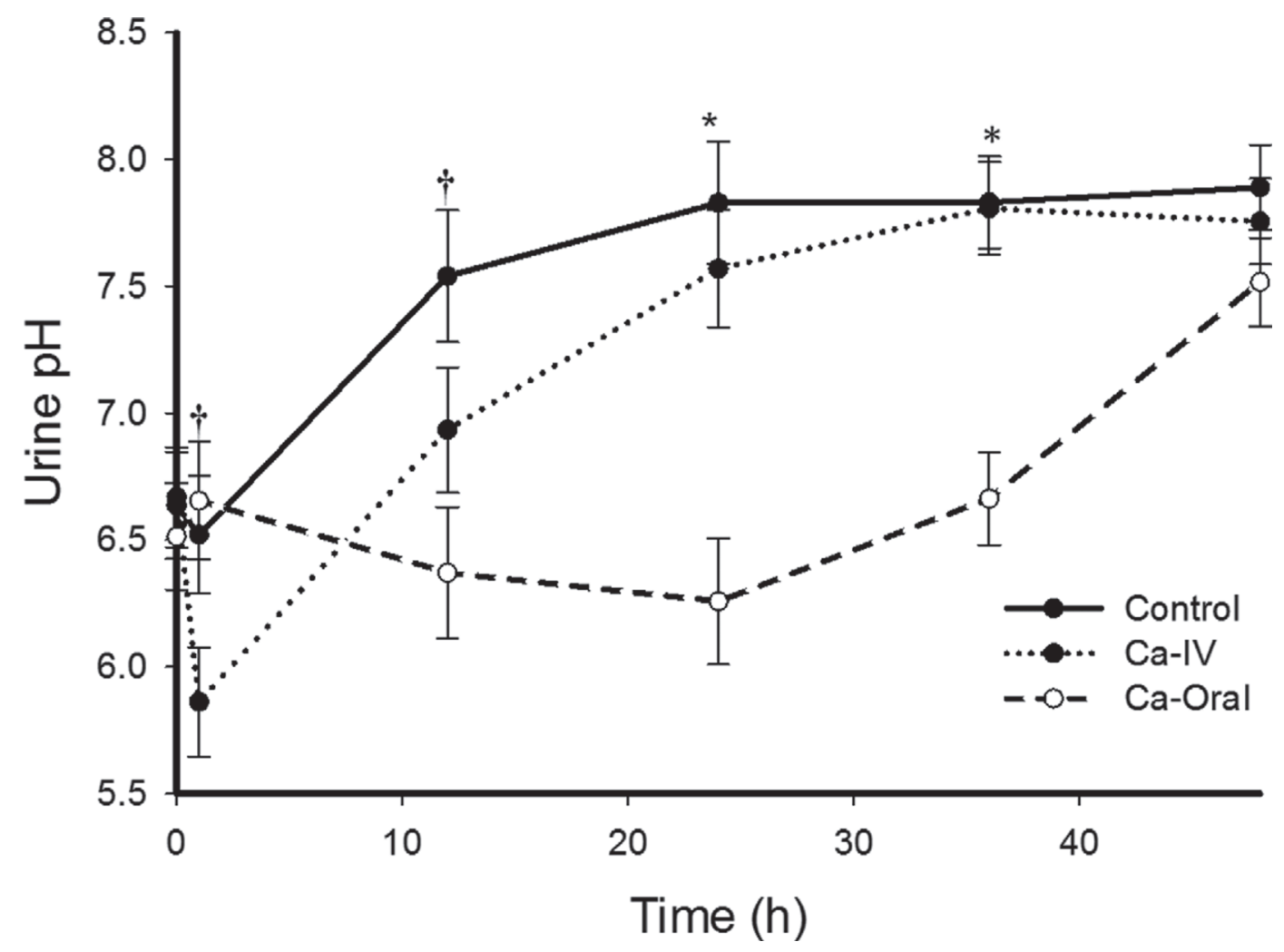

Figure 2. Urine pH levels (LSM \pm SEM) after postpartum prophylactic treatment of subclinical hypocalcemia in dairy cows in control (no Ca supplementation; $\mathrm{n}=11$ ), intravenous $\mathrm{Ca}$ [Ca-IV, $500 \mathrm{~mL}$ of $23 \%$ calcium gluconate (Durvet, Blue Springs, MO) at postpartum; $\mathrm{n}=11]$, and oral Ca [Ca-Oral, 2 Bovikalc (Boehringer Ingelheim, St. Joseph, MO) boluses $12 \mathrm{~h}$ apart at postpartum; $\mathrm{n}=11$ )]. We detected significant $(P<0.001)$ effects of treatment, time, and treatment $\times$ time interaction. Significant treatment $\times$ time differences at each time point are indicated by $\dagger(P<0.05)$ and $*(P<0.001)$. 
be associated with the iatrogenic administration of 17.5 $\mathrm{g}$ of boric acid added as a solubilizing agent of the intravenous Ca solution used. The lower urine $\mathrm{pH}$ for Ca-Oral was expected because oral $\mathrm{Ca}$ boluses (e.g., Bovikalc) are designed as anionic acidifiers and sources of $\mathrm{Ca}$ in a buffered fat coating.

Urine $\mathrm{pH}$ levels at 12,24 , and $36 \mathrm{~h}$ after treatment were lower for Ca-Oral compared with both control and Ca-IV. Urine $\mathrm{pH}$ for Ca-Oral was $\leq 6.5$ at 1,12 , and $24 \mathrm{~h}$ after treatment initiation. However, Sampson et al. (2009) reported that cows fed close-up diets with no anionic salts had alkaline urine $\mathrm{pH}$ at calving (7.6) and only $12 \mathrm{~h}$ after the administration of the second Ca bolus treatment did urine $\mathrm{pH}$ reach acidic levels (6.8).

Mean urine $\mathrm{pH}$ for cows in control group was 6.6 at $0 \mathrm{~h}$. After removing cows from their dietary source of supplemental anions, urine $\mathrm{pH}$ returned to alkaline levels (7.5) at $12 \mathrm{~h}$ after treatment initiation. Initial urine $\mathrm{pH}$ values indicated that the DCAD program was partly successful, with only 14 out of 33 cows reaching $\mathrm{pH}$ levels $<6.5$ at time of treatment application.

\section{CONCLUSIONS}

Prophylactic treatment of subclinical hypocalcemia at parturition with intravenous $\mathrm{Ca}(\mathrm{Ca}-\mathrm{IV})$ resulted in total serum $\mathrm{Ca}$ that reached hypercalcemic levels (peaking $1 \mathrm{~h}$ after treatment initiation) that later declined to hypocalcemic levels (nadir at $24 \mathrm{~h}$ ). Total serum Ca was significantly higher for Ca-IV cows at 1,2 , and 4 $\mathrm{h}$ after treatment than for control and Ca-Oral cows. However, total serum Ca was lower for Ca-IV cows than for Ca-Oral cows at 20, 24, and $36 \mathrm{~h}$, and was lower than for control cows at 36 and $48 \mathrm{~h}$. Further research is needed to evaluate the implications, for health and production, of this transient change in Ca homeostasis in Ca-IV cows.

\section{ACKNOWLEDGMENTS}

Financial support for this research was partially provided by Boehringer Ingelheim Vetmedica Inc. (St. Joseph, MO). The authors appreciate the collaboration of Pacific Rim dairy (Corcoran, CA) in allowing us to use their facilities, cows and records. Special appreciation is extended to Hilary Spivey, Cecilia Escalante, Elliot Martinez, and Jorge Gaytan (all from the College of the Sequoias, Tulare, CA); Christina Sparlin (Washington State University, Pullman); and Oscar Palomares and Jesus Aguilar (Pacific Rim Dairy, Corcoran, CA) for their diligent work during the sample collection period.

\section{REFERENCES}

Borsberry, S., and H. Dobson. 1989. Periparturient diseases and their effect on reproductive performance in five dairy herds. Vet. Rec. 124:217-219.
Braun, U., P. Zulliger, A. Liesegang, U. Bleul, and M. Hässig. 2009. Effect of intravenous calcium borogluconate and sodium phosphate in cows with parturient paresis. Vet. Rec. 164:296-299.

Chamberlin, W. G., J. R. Middleton, J. N. Spain, G. C. Johnson, M. R. Ellersieck, and P. Pithua. 2013. Subclinical hypocalcemia, plasma biochemical parameters, lipid metabolism, postpartum disease, and fertility in postparturient dairy cows. J. Dairy Sci. 96:7001-7013.

Chapinal, N., M. Carson, T. F. Duffield, M. Capel, S. Godden, M. Overton, J. E. P. Santos, and S. J. LeBlanc. 2011. The association of serum metabolites with clinical disease during the transition period. J. Dairy Sci. 94:4897-4903.

Charbonneau, E., D. Pellerin, and G. R. Oetzel. 2006. Impact of lowering dietary cation-anion difference in nonlactating dairy cows: A meta-analysis. J. Dairy Sci. 89:537-548.

Curtis, C. R., H. N. Erb, C. J. Sniffen, R. D. Smith, P. A. Powers, M. C. Smith, M. E. White, R. B. Hillman, and E. J. Pearson. 1983 Association of parturient hypocalcemia with eight periparturient disorders in Holstein cows. J. Am. Vet. Med. Assoc. 183:559-561.

Goff, J. P. 1999. Treatment of calcium, phosphorus, and magnesium balance disorders. Vet. Clin. North Am. Food Anim. Pract. 15:619-639.

Goff, J. P. 2004. Macromineral disorders of the transition cow. Vet. Clin. North Am. Food Anim. Pract. 20:471-494.

Goff, J. P., R. Ruiz, and R. L. Horst. 2004. Relative acidifying activity of anionic salts commonly used to prevent milk fever. J. Dairy Sci. $87: 1245-1255$.

Kimura, K., T. A. Reinhardt, and J. P. Goff. 2006. Parturition and hypocalcemia blunts calcium signals in immune cells of dairy cattle. J. Dairy Sci. 89:2588-2595.

Littell, R. C., P. R. Henry, and C. B. Ammerman. 1998. Statistical analysis of repeated measures data using SAS procedures. J. Anim. Sci. 76:1216-1231.

Martinez, N., C. A. Risco, F. S. Lima, R. S. Bisinotto, L. F. Greco, E. S. Ribeiro, F. Maunsell, K. Galvão, and J. E. P. Santos. 2012. Evaluation of peripartal calcium status, energetic profile, and neutrophil function in dairy cows at low or high risk of developing uterine disease. J. Dairy Sci. 95:7158-7172.

Melendez, P., A. Donovan, C. A. Risco, M. B. Hall, R. Littell, and J. P. Goff. 2002. Metabolic responses to transition Holstein cows fed anionic salts and supplemented at calving with calcium and energy. J. Dairy Sci. 85:1085-1092.

Michaylova, V., and P. Ilkova. 1971. Photometric determination of micro amounts of calcium with arsenazo III. Anal. Chim. Acta $53: 194-198$

Moore, S. J., M. J. VandeHaar, B. K. Sharma, T. E. Pilbeam, D. K. Beede, H. F. Bucholtz, J. S. Liesman, R. L. Horst, and J. P. Goff. 2000. Effects of altering dietary cation-anion difference on calcium and energy metabolism in peripartum cows. J. Dairy Sci. 83:2095-2104

Oetzel, G. R., and B. E. Miller. 2012. Effect of oral calcium bolus supplementation on early-lactation health and milk yield in commercial dairy herds. J. Dairy Sci. 95:7051-7065.

Oetzel, G. R., J. D. Olson, C. R. Curtis, and M. J. Fettman. 1988. Ammonium chloride and ammonium sulfate for prevention of parturient paresis in dairy cows. J. Dairy Sci. 71:3302-3309.

Ramos-Nieves, J. M., B. J. Thering, M. R. Waldron, P. W. Jardon, and T. R. Overton. 2009. Effects of anion supplementation to lowpotassium prepartum diets on macromineral status and performance of periparturient dairy cows. J. Dairy Sci. 92:5677-5691.

Reinhardt, T. A., J. D. Lippolis, B. J. McCluskey, J. P. Goff, and R. L. Horst. 2011. Prevalence of subclinical hypocalcemia in dairy herds. Vet. J. 188:122-124.

Roberts, T., N. Chapinal, S. J. LeBlanc, D. F. Kelton, J. Dubuc, and T. F. Duffield. 2012. Metabolic parameters in transition cows as indicators for early-lactation culling risk. J. Dairy Sci. 95:30573063.

Sampson, J. D., J. N. Spain, C. Jones, and L. Carstensen. 2009. Effects of calcium chloride and calcium sulfate in an oral bolus given as a supplement to postpartum dairy cows. Vet. Ther. 10:131-139. 